\title{
NOTE
}

\section{Host size-dependent anisakid infection in Baltic cod Gadus morhua associated with differential food preferences}

\author{
Shaozhi Zuo' ${ }^{1}$, Bastian Huwer ${ }^{2}$, Qusay Bahlool' ${ }^{1}$, Azmi Al-Jubury ${ }^{1}$, \\ Nanna Daugbjerg Christensen ${ }^{1}$, Rozalia Korbut ${ }^{1}$, Per Kania ${ }^{1}$, Kurt Buchmann ${ }^{1, *}$ \\ ${ }^{1}$ Laboratory of Aquatic Pathobiology, Department of Veterinary Disease Biology, Faculty of Health and Medical Sciences, \\ University of Copenhagen, 1870 Frederiksberg C, Denmark \\ ${ }^{2}$ National Institute of Aquatic Resources, Technical University of Denmark, 2920 Charlottenlund, Denmark
}

\begin{abstract}
A significant increase in the infection level of Baltic cod Gadus morhua with the anisakid nematode larvae Contracaecum osculatum and Pseudoterranova decipiens has been recorded during recent years due to the expanding local population of grey seals Halichoerus grypus, which act as final hosts for these parasites. Here, we report from an investigation of 368 cod (total length [TL] 6-49 cm; caught in ICES Subdivision 25) that the infection level of juvenile cod (TL 6-30 cm) with larvae of C. osculatum and P. decipiens is absent or very low, whereas it increases drastically in larger cod (TL 31-48 cm). A third nematode Hysterothylacium aduncum was rarely found. The study indicates that the prey animals for large cod act as transport hosts for the parasite larvae. Analyses of stomach contents of cod caught in the same area (2007-2014) showed that small benthic organisms (including polychaetes Harmothoë sarsi) are preferred food items by small cod, the isopod Saduria entomon is taken by all size classes, and sprat Sprattus sprattus are common prey items for cod larger than $30 \mathrm{~cm}$. Parasitological investigations (microscopic and molecular analyses) of $H$. sarsi (100 specimens) and $S$. entomon (40 specimens) did not reveal infection in these invertebrates, but $11.6 \%$ of sprat ( 265 specimens examined) was shown to be infected with 1-8 C. osculatum third stage larvae per fish. Analyses of sprat stomach contents confirmed that copepods and cladocerans are the main food items of sprat. These observations suggest that the C. osculatum life cycle in the Baltic Sea includes grey seals as final hosts, sprat as the first transport host and cod as second transport host. It may be speculated that sprat obtain infection by feeding on copepods and/or cladocerans, which could serve as the first intermediate hosts. One cannot exclude the possibility that the size-dependent $C$. osculatum infection of cod may contribute (indirectly or directly) to the differential mortality of larger cod $(>38 \mathrm{~cm})$ compared to smaller cod $(<30 \mathrm{~cm})$ recently recorded in the Baltic cod population.
\end{abstract}

KEY WORDS: Gadus morhua · Halichoerus grypus · Contracaecum osculatum · Pseudoterranova decipiens $\cdot$ Hysterothylacium aduncum $\cdot$ Life cycle $\cdot$ Sprattus sprattus $\cdot$ Saduria $\cdot$ Harmothoë

\section{INTRODUCTION}

Baltic cod is a stationary local strain of the Atlantic cod Gadus morhua inhabiting the Baltic Sea, a semienclosed brackish water area connected to the North Sea through the narrow Danish straits. It is divided

\footnotetext{
*Corresponding author: kub@sund.ku.dk
}

into an eastern and western stock with a mixing zone around the island of Bornholm (Bagge et al. 1994, Hüssy et al. 2016). During recent years a marked increase in the infection level of third-stage larvae of Contracaecum osculatum and Pseudoterranova decipiens in Baltic cod has been observed

() The authors 2016. Open Access under Creative Commons by Attribution Licence. Use, distribution and reproduction are unrestricted. Authors and original publication must be credited. 
(Perdiguero-Alonso et al. 2008, Buchmann \& Kania 2012, Haarder et al. 2014, Mehrdana et al. 2014, Nadolna \& Podolska 2014). This development has been noted during a period with a marked increase of the grey seal Halichoerus grypus population (Haarder et al. 2014). These pinnipeds are final hosts for both $C$. osculatum and $P$. decipiens (Marcogliese et al. 1996, McClelland 2002, Mattiucci \& Nascetti 2008, Skrzypczak et al. 2014, Lunneryd et al. 2015). Eero et al. (2015) suggested that heavy C. osculatum liver infections may partly explain the distress of the eastern population of Baltic cod, where juveniles (<30 cm total length [TL]) perform successfully but larger cod (>38 cm TL) show increased mortality. However, so far no parasitological studies on the infection of juvenile stages of Baltic cod are available, and it is therefore important to address this question. We conducted a basic parasitological investigation of different size classes (TL 6-49 $\mathrm{cm}$ ) of Baltic cod caught by the research vessel 'DANA' from 2013 to 2015 in order to elucidate any sizedependent infection with larval nematodes. In addition, stomach content analyses of cod from the same size classes were obtained in order to find putative intermediate/transport hosts for the parasite larvae. Samples of main prey organisms identified were then caught during the same research cruises and subsequently examined for presence of parasite larvae.

\section{MATERIALS AND METHODS}

\section{Sampling area and fish}

A total of 368 Baltic cod Gadus morhua (TL 6-49 cm) were examined for presence of parasites (see Table 1). Fish were collected by trawl (water depth $57-77 \mathrm{~m} ; 54.45^{\circ}$ to $55.45^{\circ} \mathrm{N}, 014.30^{\circ}$ to $016.30^{\circ} \mathrm{E}$ ) from 2013 to 2015 during cruises with RV 'DANA' (National Institute of Aquatic Resources, Technical University of Denmark) except for 11 cod taken by a local fisherman (trawl) at position $55.04^{\circ} \mathrm{N}, 014.50^{\circ} \mathrm{E}$. Fish were frozen immediately after catch and kept at $-20^{\circ} \mathrm{C}$ until investigation. We also included examination of 265 specimens of sprat Sprattus sprattus (TL 11-13 cm) caught by RV 'DANA' by trawl in the same area and treated as described above. Cod samples from RV 'DANA' were obtained using a TV3 bottom trawl, while sprat samples were obtained by both TV3 bottom trawl and FOTØ pelagic trawl. Samples of Saduria entomon and Harmothoe sarsi were caught in the same area with a $1 \mathrm{~m}$ dredge and a $2 \mathrm{~m}$ beam trawl.

\section{Stomach content analysis}

Stomach content recordings from 5363 specimens of Baltic cod (TL 5-50 cm) caught during cruises with RV 'DANA' in ICES Subdivision (SD) 25 in the period 2007-2014 were analysed. Sampling and analysis methodology has previously been described by Huwer et al. (2014). In brief, stomachs were removed from cod, frozen at $-20^{\circ} \mathrm{C}$ on board and transported to the laboratory, where they were thawed, opened, and stomach contents inspected macroscopically. The ingested prey was characterized as (1) Saduria entomon, (2) other crustaceans, (3) other benthos, (4) Harmothoë sarsi, (5) sprat Sprattus sprattus, or (6) herring Clupea harengus. The stomach content of 10 specimens of sprat (caught by pelagic trawling in SD25) was spread on microscope slides and examined under the microscope (100-400× magnification) (Leica DM 5000 B).

\section{Parasitological investigation of cod}

Following thawing of frozen cod we measured TL (cm) and total body weight $(\mathrm{g})$ for each fish. Each fish was decapitated, internal organs removed and the musculature (fillet part) was removed and examined according to Karl \& Leinemann (1993). Briefly, plastic bags of $400 \times 200 \mathrm{~mm}$ were used for the fillet and then compressed to a layer of around $2 \mathrm{~mm}$ thickness using a $12 \mathrm{t}$ hydraulic shop press (AJ Engros). The compressed bags with fish were frozen at $-40^{\circ} \mathrm{C}$ for $24 \mathrm{~h}$ before further analysis. The compressed samples were exposed to a $302 \mathrm{~nm}$ UV light using MacroVue ${ }^{\mathrm{TM}}$ UV-20 Transilluminator (Hoefer ${ }^{\circledR}$ ) in a dark room, and any white-bluish fluorescence from worms was observed and marked. Detected nematodes were carefully withdrawn from the muscle tissue for further analysis. Internal organs including cod livers were compressed in other plastic bags as described above, but because C. osculatum larvae in liver tissue do not fluoresce under UV-light, the compressed organs were scrutinized under the dissection microscope (8-100x magnification) (Leica MZ125). Nematodes were counted, isolated and identified using light microscopy and PCR with subsequent sequencing according to Mehrdana et al. (2014) as described below. 


\section{Parasitological investigation of prey organisms}

A total of 100 Harmothoë sari and 40 S. entomon specimens were dissected and examined under the dissection microscope for occurrence of worm larvae. All soft parts were subsequently removed and conserved in $96 \%$ ethanol for further processing including lysis, DNA purification and PCR detection of worm-specific DNA. We used the QIAamp DNA stool Mini kit (Cat. No. 515004) for extraction of DNA according to the manufacturer's instructions. A total of 265 specimens of sprat $S$. sprattus were examined for occurrence of worm larvae with the same methods used for cod as described above.

\section{Morphological and molecular nematode identification}

All recovered nematodes were examined under the light microscope (Leica DM 5000 B) for genus determination (Mehrdana et al. 2014). Nematodes were subsequently preserved in $96 \%$ ethanol (CCS Health Care) for further molecular identification. The middle part of the nematode larva was cut out aseptically and incubated in $100 \mu$ lysis buffer $(0.45 \%$, Tween 20, $60 \mu \mathrm{m} \mathrm{ml}^{-1}$, Proteinase $\mathrm{K}, 10 \mathrm{mM}$ Tris and $1 \mathrm{mM}$ EDTA) at $55^{\circ} \mathrm{C}, 450 \mathrm{rpm}$, in the Eppendorf Thermomixer Comfort (Eppendorf AG). Incubation time varied but continued until complete digestion. Proteinase $\mathrm{K}$ was then deactivated at $95^{\circ} \mathrm{C}$ for $10 \mathrm{~min}$, and the lysate was used for PCR amplification. In order to ensure that no worm material was left undetected in $H$. sarsi and $S$. entomon, we also performed PCR on DNA extracted from ethanol conserved soft parts of these invertebrates. PCR was performed in a Biometra T3 thermocycler (Fisher Scientific) using $60 \mu$ l reaction volumes. The reaction mixtures consisted of $6 \mu$ lysate as template, 1 unit of BioTaq DNA polymerase (DNA-Technology), $1 \mathrm{mM}$ dNTP, $1.5 \mathrm{mM} \mathrm{MgCl}_{2}$ and $1 \mu \mathrm{M}$ of the 2 primers. In order to amplify the internal transcribed spacer (ITS) region, the primers NC5 (5'-GTA GGT GAA CCT GCG GAA GGA TCA TT-3') and NC2 (5'-TTA GTT TCT TTT CCT CCG CT-3') were used as forward and reverse primer, respectively (Zhu et al. 2007). PCR conditions were 2 min of pre-denaturation at $94^{\circ} \mathrm{C}$ followed by 36 cycles of denaturation at $94^{\circ} \mathrm{C}$ for $30 \mathrm{~s}$, annealing at $53^{\circ} \mathrm{C}$ for $30 \mathrm{~s}$ and elongation at $72^{\circ} \mathrm{C}$ for $1 \mathrm{~min} 15 \mathrm{~s}$. Finally, a post-elongation step was performed at $72^{\circ} \mathrm{C}$ for $7 \mathrm{~min}$. Products were analysed by $2 \%$ ethidium bromide-stained agarose gels. PCR products were purified using Illustra GF PCR and the Gel Band Purification kit (GE Healthcare, cat. no. 28-9034-71) according to the manufacturer's instructions prior to sequencing at Macrogen Inc. Species identification was based on the sequences encoding the ITS region (18S [ $3^{\prime}$ end], ITS-1, 5.8S rRNA, ITS-2, and 28S rRNA [5' end]).

\section{Statistics and calculations}

Stomach content of cod was expressed as the percentage of all stomachs in a certain size class (frequency of occurrence) carrying a certain prey organism. The infection percentages of cod and the mean number of worms per infected fish in the different size classes were calculated. Differences were evaluated by the Mann-Whitney $U$-test. Microsoft Excel 2007 and SigmaPlot 12.5 were used for statistical calculations. A probability level of $5 \%$ was used for all analyses.

\section{RESULTS}

\section{Parasite infections}

Baltic cod with TL below $20 \mathrm{~cm}$ showed none or very low infections with nematode larvae. A few fish (TL 21-30 cm) harboured a low infection (1 to 2 parasites per fish) but only with Contracaecum osculatum (Table 1, Fig. 1). The occurrence of both C. osculatum and Pseudoterranova decipiens increased with host size from 31 to $49 \mathrm{~cm}$, particularly with regard to the first species. More than $87 \%$ of larger cod harboured C. osculatum larvae with a mean number of 16 parasites per fish. A few specimens of a third nematode species Hysterothylacium aduncum, using fish as both intermediate and final hosts, were found in fish larger than TL $41 \mathrm{~cm}$. Third stage larvae recovered were identified as C. osculatum (92\% of worms recovered), $P$. decipiens (5\% of worms) and $H$. aduncum $(3 \%)$ (Table 1). No worm infections were detected in Harmothoë sarsi and Saduria entomon by any method, but sprat was found infected (liver) with $C$. osculatum $(11.6 \%, 1-8$ parasites per fish, mean no. of parasites per infected fish $=1.6$ ) and $H$. aduncum $(0.4 \%$, mean no. of parasites per fish $=1.0)$.

\section{Stomach analyses}

Small benthic invertebrates (including $H$. sarsi polychaetes) were preferred by the smallest cod. The 
Table 1. Prevalence (P) and mean intensity (I) of nematodes infecting muscle and liver of Baltic cod (various size classes) from ICES Subdivision 25 (Bornholm Basin). Third stage larvae recovered from cod listed as 'All anisakids', Contracaecum osculatum, Pseudoterranova decipiens, or Hysterothylacium aduncum. * Significantly different from size classes $1-10,11-20$ and $21-30 \mathrm{~cm}(\mathrm{p}<0.05)$

\begin{tabular}{|c|c|c|c|c|c|}
\hline \multirow{2}{*}{$\begin{array}{l}\text { Size } \\
\text { class (cm) }\end{array}$} & \multirow{2}{*}{$\begin{array}{l}\text { No. of } \\
\text { fish }\end{array}$} & \multicolumn{2}{|c|}{ Muscle infections } & \multicolumn{2}{|c|}{ Liver infections } \\
\hline & & $\mathrm{P}(\%)$ & I & $\mathrm{P}(\%)$ & I \\
\hline \multicolumn{6}{|c|}{ All anisakids } \\
\hline $1-10$ & 53 & 0 & 0 & 0 & 0 \\
\hline $11-20$ & 194 & 0 & 0 & 2.06 & 1 \\
\hline $21-30$ & 21 & 9.52 & 1 & 28.57 & 2 \\
\hline $31-40$ & 53 & 3.77 & 1.5 & $75.47^{*}$ & 16.1 \\
\hline $41-50$ & 47 & 6.38 & 1.67 & $87.23^{*}$ & $16.24^{*}$ \\
\hline All classes & 368 & 1.9 & 1.43 & 25.82 & 13.96 \\
\hline \multicolumn{6}{|c|}{ Contracaecum osculatum } \\
\hline $1-10$ & 53 & 0 & 0 & 0 & 0 \\
\hline $11-20$ & 194 & 0 & 0 & 2.06 & 1 \\
\hline $21-30$ & 21 & 9.52 & 1 & 28.57 & 2 \\
\hline $31-40$ & 53 & 0 & 0 & $75.47^{*}$ & 16.1 \\
\hline $41-50$ & 47 & 0 & 0 & $87.23^{*}$ & $16.24^{*}$ \\
\hline All classes & 368 & 0.27 & 1 & 25.82 & 13.96 \\
\hline \multicolumn{6}{|c|}{ Pseudoterranova decipiens } \\
\hline $1-10$ & 53 & 0 & 0 & 0 & 0 \\
\hline $11-20$ & 194 & 0 & 0 & 0 & 0 \\
\hline $21-30$ & 21 & 0 & 0 & 0 & 0 \\
\hline $31-40$ & 53 & 3.77 & 1.5 & 0 & 0 \\
\hline $41-50$ & 47 & 4.26 & 2 & 0 & 0 \\
\hline All classes & 368 & 1.09 & 1.75 & 0 & 0 \\
\hline \multicolumn{6}{|c|}{ Hysterothylacium aduncum } \\
\hline $1-10$ & 53 & 0 & 0 & 0 & 0 \\
\hline $11-0$ & 194 & 0 & 0 & 0 & 0 \\
\hline $21-30$ & 21 & 0 & 0 & 0 & 0 \\
\hline $31-40$ & 53 & 0 & 0 & 0 & 0 \\
\hline $41-50$ & 47 & 2.13 & 1 & 0 & 0 \\
\hline All classes & 368 & 0.27 & 1 & 0 & 0 \\
\hline
\end{tabular}

isopod S. entomon was found both in small and larger cod. Sprat Sprattus sprattus dominated (up to $30 \%$ ) the stomach content of fish with TL $>21 \mathrm{~cm}$ (Fig. 1b). Herring Clupea harengus was also represented in the largest cod but at a lower rate $(<10 \%)$. The sprat stomach content was analysed by microscopy which revealed that copepods (Temora longicornis, Centropages hamatus) and cladocerans Bosmina sp. dominated the sprat stomach contents.

\section{Molecular analyses of worms}

Molecular analyses of the ITS region of nematode larvae recovered confirmed the identity of the microscopical analysis. In all sequences from C. osculatum, a fragment of 931 nucleotides, excluding the primer binding site, was obtained. The ITS region was se- quenced from the $3^{\prime}$ end of the $18 \mathrm{~S}$ ribosomal rRNA to the $5^{\prime}$ end of the $28 \mathrm{~S}$ ribosomal rRNA. ITS sequences obtained from $C$. osculatum recovered from cod and sprat corresponded (GenBank accession numbers for parasites in cod KU306614-306694 and in sprat KU306695-306696) and showed the highest identity with GenBank accession no. AF411203 for C. osculatum found in Halichoerus grypus from the Baltic Sea (Bothnian Bay). The sequence similarity was 99.8 to $100 \%$ identical to previously recorded GenBank accession numbers. Sequence analyses of corresponding rDNA from P. decipiens (KU306721) and $H$. aduncum (KU306719 and KU306720) showed full identity to GenBank sequences from those species isolated from North Sea fish (Atlantic cod and eel-pout, respectively).

\section{DISCUSSION}

The present study documented differential nematode infection rates of various size classes of Baltic cod. Small cod remain uninfected or merely lightly infected whereas cod $>30 \mathrm{~cm}$ TL experience increasing infections especially with Contracaecum osculatum larvae. The life cycle of this anisakid was elucidated in the laboratory by Køie \& Fagerholm (1995), who showed that various invertebrates, including copepods, serve as first intermediate hosts. These crustaceans become infected when they feed on nematode larvae released from the parasite eggs delivered by seal. A dominance of adult C. osculatum in Baltic grey seal stomachs was previously documented by Skrzypczak et al. (2014) and Lunneryd et al. (2015), and the increase of fish infections during the last decades may be caused by the rapidly expanding grey seal population (Haarder et al. 2014). Several fish species are able to obtain infection when ingesting the first intermediate hosts, and the present field study documented that more than $10 \%$ of the Baltic sprat investigated was infected by up to 8 parasite larvae per fish, which is a higher infection level than previously reported. In 2009 and 2011 only 2 Baltic sprat out of the 187 examined harboured infection (1 larva per fish) (Skrzypczak \& Rolbiecki 2015). It may be hypothesized that Baltic cod in SD25 obtain infection with C. osculatum when cod (reaching a TL of $30 \mathrm{~cm}$ ) physically become able to ingest sprat. Corresponding dynamic associations between cod size, diet and parasites have been recorded previously in Atlantic cod (Münster et al. 2015). It may be speculated that the sprat become infected when feeding on infected copepods and/or cladocerans, although 

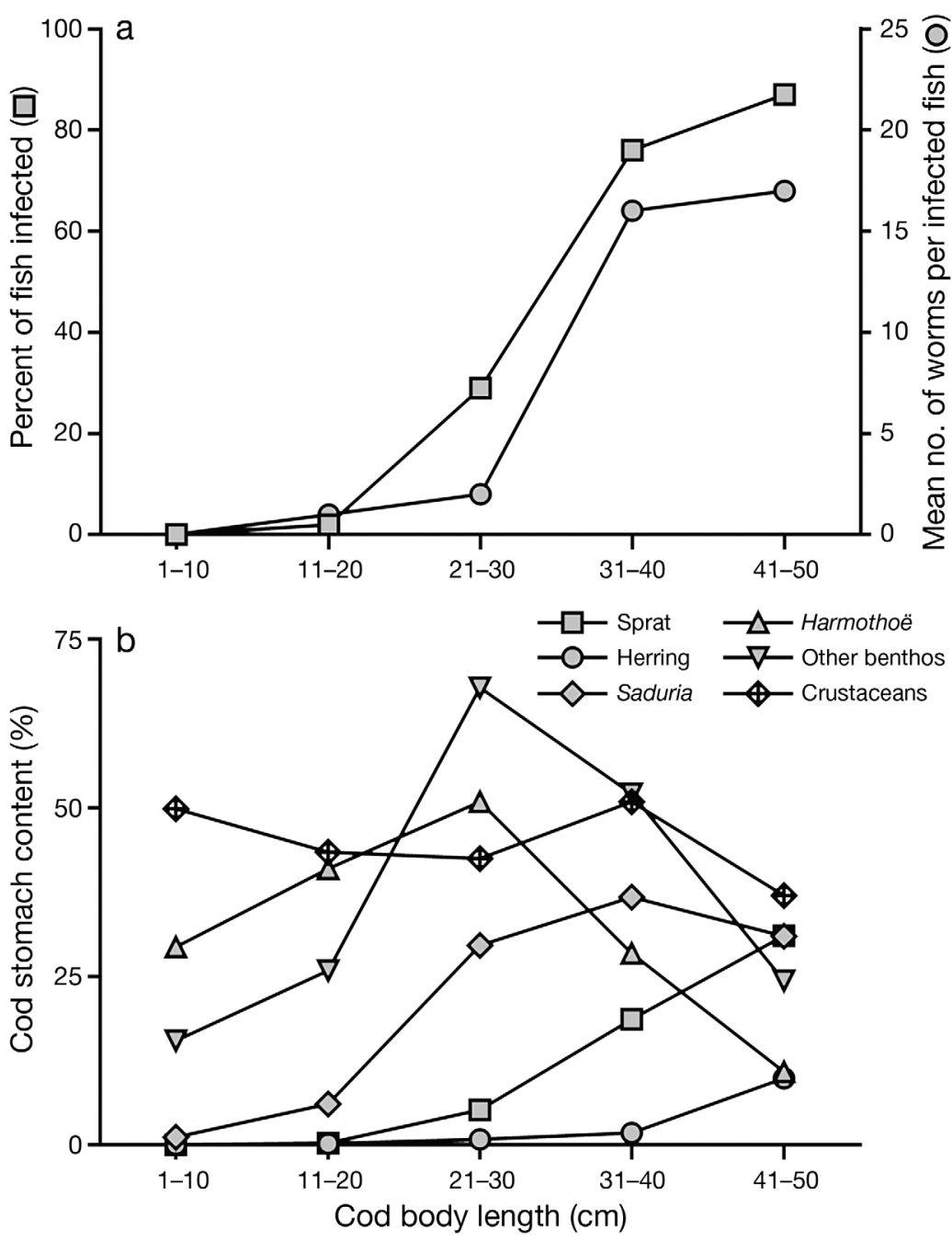

Fig. 1. (a) Percentage of Baltic cod infected with Contracaecum osculatum and number of larvae per infected fish in ICES Subdivision 25 (Bornholm Basin) according to size class. (b) Stomach content of cod in the Baltic Sea according to size class. Saduria: Saduria entomon; Harmothoë: Harmothoë sarsi

larger numbers of invertebrates in order to elucidate their potential role as intermediate hosts.

The finding that smaller cod remain uninfected or merely lightly infected until they reach a TL of $30 \mathrm{~cm}$ may have implications for the ecology of this fish species in the eastern Baltic Sea. During the last decade, a high survival rate and increasing numbers have been recorded for small cod (TL $<30 \mathrm{~cm}$ ) whereas the population of larger cod (TL > $38 \mathrm{~cm}$ ) has exhibited a drastic and unexpected decline (Eero et al. 2015). Direct predation on cod by seals has been suggested to have caused a reduction in Canadian fish stocks (Chouinard et al. 2005, Swain \& Chouinard 2008, Swain \& Benoit 2015), and predation may play a role for the Baltic cod as well. However, it may be speculated that parasite infections, mainly due to $C$. osculatum, indirectly affect the performance of the Baltic cod population. Experimental infections of fish with anisakid larvae (Pseudoterranova and Anisakis) have shown pathological effects in fish tissue (Ramakrishna et al. 1993, Buchmann 2012, Levsen \& Berland 2012), depression of host swimming performance (Sprengel \& Lüchtenberg 1991) and reduced levels of survival (Rohlwing et al. 1998). The pathogenic potential of Pseudoterranova and Contracaecum larvae is further emphasized by the severe inflammatory reactions induced at the

we did not document infection in these planktonic organisms. However, they occur throughout the year all over the Baltic (Ackefors 1969) and are the dominating food elements in sprat (Casini et al. 2004). Baltic herring was included in the Baltic cod diet at a lower rate, but this fish species may also play a role in C. osculatum transmission as they may carry, although at a low level, larvae of this nematode (Unger et al. 2014). We were not able, in this study, to detect infection of polychaetes (Harmothoë sarsi) and isopods (Saduria entomon), but we cannot rule out the possibility that at least part of the infection of cod may be obtained during feeding on these invertebrates. Thus, invertebrate intermediate hosts are generally infected at low prevalences and intensities, and future parasitological studies should include penetration site when these parasites infect the stomach of mammals including humans (Schaum \& Müller 1967, Shamsi \& Butcher 2011, Nagasawa 2012, Strøm et al. 2015). Based on these studies it may be hypothesized that the most heavily infected (larger) fish become more vulnerable to predation. The increased and unexpected mortality of larger cod could thereby be associated (directly or indirectly) with an increased level of infection, but this notion should be further investigated by controlled infection studies in the laboratory.

Acknowledgements. The present study was supported by the EU commission under the Seventh Framework Programme for Research, Technological Development and Demonstration under grant agreement no. 312068 for the 
project PARASITE. Sampling was done by the BONUS BIOC3 project supported by BONUS (Art 185), funded jointly by the EU and Innovation Fund Denmark. The BIO-C3 cruise on RV 'DANA' in September 2015 was funded by the Danish Centre for Marine Research (grant 2015-04).

\section{LITERATURE CITED}

Ackefors H (1969) Ecological zooplankton investigations in the Baltic proper 1963-1965. Inst Mar Res Lysekil Ser Biol Rep 18:1-139

Bagge O, Thurow F, Steffensen E, Bay J (1994) The Baltic cod. Dana 10:1-28

Buchmann K (2012) Fish immune responses against endoparasitic nematodes - experimental models. J Fish Dis 35:623-635

- Buchmann K, Kania P (2012) Emerging Pseudoterranova decipiens (Krabbe, 1878) problems in Baltic cod, Gadus morhua L., associated with grey seal colonization of spawning grounds. J Fish Dis 35:861-866

> Casini M, Cardinale M, Arrhenius F (2004) Feeding preferences of herring (Clupea harengus) and sprat (Sprattus sprattus) in the southern Baltic Sea. ICES J Mar Sci 61: 1267-1277

Chouinard GA, Swain DP, Hammill MO, Poirier GA (2005) Covariation between grey seal (Halichoerus grypus) abundance and natural mortality of cod (Gadus morhua) in the southern Gulf of St. Lawrence. Can J Fish Aquat Sci 62:1991-2000

Eero M, Hjelm J, Behrens J, Buchmann K and others (2015) Eastern Baltic cod in distress: biological changes and challenges for stock assessment. ICES J Mar Sci 72: 2180-2186

Haarder S, Kania PW, Galatius A, Buchmann K (2014) Increased Contracaecum osculatum infection in Baltic cod (Gadus morhua) livers (1982-2012) associated with increasing grey seal (Halichoerus gryphus) populations. J Wildl Dis 50:537-543

> Hüssy K, Hinrichsen HH, Eero M, Mosegaard H, HemmerHansen J, Lehmann A, Lundgaard LS (2016) Spatio-temporal trends in stock mixing of eastern and western Baltic cod in the Arkona Basin and the implications for recruitment. ICES J Mar Sci 73:293-303

Huwer B, Neuenfeldt S, Rindorf A, Andreasen H and others (2014) Study on stomach content of fish to support the assessment of good environmental status of marine food webs and the prediction of MSY after stock restoration. Final report for EU contract No. MARE/2012/02. DTU AquaNational Institute of Aquatic Resources, Copenhagen

Karl H, Leinemann M (1993) A fast and quantitative detection method for nematodes in fish fillets and fishery products. Arch Lebensmittelhyg 44:124-125

Køie M, Fagerholm HP (1995) The life-cycle of Contracaecum osculatum (Rudolphi, 1802) sensu stricto (Nematoda, Ascaridoidea, Anisakidae) in view of experimental infections. Parasitol Res 81:481-489

Levsen A, Berland B (2012) Anisakis species. In: Woo PTK, Buchmann K (eds) Fish parasites: pathobiology and protection. CAB International, Wallingford, p 298-309

> Lunneryd SG, Bostrom MK, Aspholm PE (2015) Sealworm (Pseudoterranova decipiens) infection in grey seals (Halichoerus grypus), cod (Gadus morhua) and shorthorn sculpin (Myoxocephalus scorpius) in the Baltic Sea. Parasitol Res 114:257-264
Marcogliese DJ, Boily F, Hammill MO (1996) Distribution and abundance of stomach nematodes (Anisakidae) among grey seals (Halichoerus grypus) and harp seals (Phoca groenlandica) in the Gulf of St. Lawrence. Can J Fish Aquat Sci 53:2829-2836

Mattiucci S, Nascetti G (2008) Advances and trends in the molecular systematics of anisakid nematodes, with implications for their evolutionary ecology and host-parasite co-evolutionary processes. Adv Parasitol 66:47-148

> McClelland G (2002) The trouble with sealworms (Pseudoterranova decipiens species complex, Nematoda): a review. Parasitology 124:S183-S203

Mehrdana F, Bahlool QZ, Skov J, Marana MH and others (2014) Occurrence of zoonotic nematodes Pseudoterranova decipiens, Contracaecum osculatum and Anisakis simplex in cod (Gadus morhua) from the Baltic Sea. Vet Parasitol 205:581-587

Münster J, Klimpel S, Fock HO, MacKenzie K, Kuhn T (2015) Parasites as biological tags to track an ontogenetic shift in the feeding behaviour of Gadus morhua off West and East Greenland. Parasitol Res 114:2723-2733

> Nadolna K, Podolska M (2014) Anisakid larvae in the liver of cod (Gadus morhua) L. from the southern Baltic Sea. J Helminthol 88:237-246

Nagasawa K (2012) The biology of Contracaecum osculatum sensu lato and C. osculatum A (Nematoda: Anisakidae) in Japanese waters: a review. Biosphere Sci 51:61-69

> Perdiguero-Alonso D, Montero F, Raga JA, Kostadinova A (2008) Composition and structure of the parasite faunas of cod, Gadus morhua L. (Teleostei: Gadidae) in the North East Atlantic. Parasit Vectors 1:23

Ramakrishna NR, Burt MDB, MacKinnon BM (1993) Cellmediated immune response of rainbow trout (Oncorhynchus mykiss) to larval Pseudoterranova decipiens (Nematoda; Ascaridoidea) following sensitization to live sealworm, sealworm extract and nonhomologous extracts. Can J Fish Aquat Sci 50:60-65

> Rohlwing T, Palm HW, Rosenthal H (1998) Parasitisation with Pseudoterranova decipiens (Nematoda) influences the survival rate of the European smelt Osmerus eperlanus retained by a screen wall of a nuclear power plant. Dis Aquat Org 32:233-236

Schaum E, Müller W (1967) Die Heterocheilidiasis. Eine Infektion des Menschen mit Larven von Fisch-Ascariden. Dtsch Med Wochenschr 92:2230-2233

Shamsi S, Butcher AR (2011) First report of human anisakidosis in Australia. Med J Aust 194:199-200

> Skrzypczak M, Rolbiecki L (2015) Endoparasitic helminths of the European sprat, Sprattus sprattus (Linnaeus, 1758) from the gulf of Gdansk (the Southern Baltic Sea) with a checklist of its parasites. Russ J Mar Biol 41:167-175

> Skrzypczak M, Rokicki J, Pawliczka I, Najda K, Dzido J (2014) Anisakids of seals found on the southern coast of Baltic Sea. Acta Parasitol 59:165-172

> Sprengel G, Lüchtenberg H (1991) Infection by endoparasites reduces maximum swimming speed of European smelt Osmerus eperlanus and European eel Anguilla anguilla. Dis Aquat Org 11:31-35

> Strøm SB, Haarder S, Korbut R, Mejer H, Thamsborg SM, Kania PW, Buchmann K (2015) Third-stage nematode larvae of Contracaecum osculatum from Baltic cod (Gadus morhua) elicit eosinophilic granulomatous reactions when penetrating the stomach mucosa of pigs. Parasitol Res 114:1217-1220 
Swain DP, Benoit HP (2015) Extreme increases in natural mortality prevent recovery of collapsed fish populations in a Northwest Atlantic ecosystem. Mar Ecol Prog Ser 519:165-182

Swain DP, Chouinard GA (2008) Predicted extirpation of the dominant demersal fish in a large marine ecosystem: Atlantic cod (Gadus morhua) in the Southern Gulf of St. Lawrence. Can J Fish Aquat Sci 65:2315-2319

Editorial responsibility: Sven Klimpel,

Frankfurt, Germany
Unger P, Klimpel S, Lang T, Palm HW (2014) Metazoan parasites from herring (Clupea harengus L.) as biological indicators in the Baltic Sea. Acta Parasitol 59:518-528

> Zhu XQ, Podolska M, Liu JS, Yu HQ and others (2007) Identification of anisakid nematodes with zoonotic potential from Europe and China by single-strand conformation polymorphism analysis of nuclear ribosomal DNA. Parasitol Res 101:1703-1707

Submitted: December 22, 2015; Accepted: April 4, 2016 Proofs received from author(s): May 25, 2016 